\title{
COMPARATIVE DICLOFENAC DETECTION FOR CHRONIC TOXICITY LEVELS USING WATER SOLUBLE Zn-METALLOPORPHYRIN, GOLD NANOPARTICLES AND THEIR HYBRID
}

\author{
ANCA PALADE ${ }^{1}$, ANCA LASCU $^{1} *$, IONELA FRINGU ${ }^{1}$, LUMINITA SALAGEANU ${ }^{2}$, DANA \\ VLASCICI $^{3}$, MIHAELA BIRDEANU ${ }^{4}$, EUGENIA FAGADAR-COSMA ${ }^{1}$ \\ ${ }^{I}$ Institute of Chemistry Timișoara of Romanian Academy, M. Viteazul Ave. 24, 300223, Timişoara, Romania, \\ ${ }^{2}$ Health Insurance House Timiș, Corbului Street 4, 300239-Timișoara, Romania \\ ${ }^{3}$ West University of Timisoara, Faculty of Chemistry-Biology-Geography, Pestalozzi Street 16, 300115, Timișoara, Romania, \\ ${ }^{4}$ National Institute for Research and Development in Electrochemistry and Condensed Matter, 1 Plautius Andronescu Street, \\ 300224, Timișoara, Romania
}

*corresponding author: ancalascu@yahoo.com

Manuscript received: May 2017

\begin{abstract}
The optical detection of chronic toxicity levels of diclofenac were comparatively investigated using novel nanostructured materials, such as: a water soluble metalloporphyrin: $\mathrm{Zn}$ (II)-tetra-(4-N-methyl-4-pyridyl)porphyrin tetrachloride (ZnTMePyP), tailored size spherical gold nanoparticles $(\mathrm{n}-\mathrm{Au})$ of $15-20 \mathrm{~nm}$, and the hybrid nanomaterial $(\mathrm{ZnTMePyP} / \mathrm{n}-$ $\mathrm{Au}$ ) formed between them. After spectroscopic and microscopic analyses, it can be stated that the water soluble Zn-porphyrin alone can detect diclofenac in a larger domain of concentration $\left(2.57 \times 10^{-5}-14.15 \times 10^{-5} \mathrm{~mol} / \mathrm{L}\right)$ than the hybrid formed between the metalloporphyrin and $\mathrm{n}-\mathrm{Au}$ and that the gold nanoparticles alone are not capable of diclofenac detection.
\end{abstract}

\section{Rezumat}

A fost investigată capacitatea unor noi materiale nanostructurate de a detecta prin spectroscopie UV-Vis concentrații de diclofenac din domeniul relevant toxicității cronice, utilizând o metaloporfirină solubilă în apă, și anume: tetraclorura de Zn(II)-tetra-(4-N-metil-4-piridil)porfirina (ZnTMePyP), nanoparticule sferice de aur (n-Au) cu dimensiune controlată (15 - $20 \mathrm{~nm}$ în diametru) precum și materialul hibrid format între ele (ZnTMePyP/n-Au). În urma analizelor spectroscopice și microscopice efectuate s-a constatat că Zn-porfirina folosită singură poate detecta un domeniu mai larg de concentrații de diclofenac $\left(2.57 \times 10^{-5}\right.$ $14.15 \times 10^{-5} \mathrm{~mol} / \mathrm{L}$ ) decât hibridul format intre ea și n-Au, precum și că nanoparticulele de aur nu au capacitate de detecție pentru diclofenac.

Keywords: diclofenac, Zn-metalloporphyrin, gold nanoparticles, gold-porphyrin hybrid, UV-Vis spectroscopy

\section{Introduction}

Diclofenac, 2-[(2,6-dichlorophenyl)-amino]-benzeneacetic acid, is a synthetic nonsteroidal anti-inflammatory analgesic drug [10], pharmaceutically formulated as different salts, usually as potassium and sodium. The drug is used to treat rheumatoid arthritis, osteoarthritis $[22,16]$, musculoskeletal injuries [38], ankle sprain injuries $[28,29]$ and is administered as post-surgery analgesic in human and veterinary medicine [23]. Many patients taking diclofenac for arthritis also need additional drugs for other chronic health problems such as hypertension [40].

Diclofenac may inhibit L-type calcium channels which participate in pain perception [54] and this is the reason why this drug is widely indicated to decrease morphine consumption after surgery in adults [43], for degenerative joint disease [35], chronic pain associated with cancer and kidney stones [26] and endodontic procedures [32].
Despite its benefic actions, diclofenac needs a cotreatment agent as a therapeutic strategy to attenuate the gastrointestinal tract complications leading to gastric ulcer disease $[10,51]$.

Metabolites of diclofenac are eliminated in the urine and the mean terminal elimination half-life was determined to be 88.4 hours [21].

Knowing the limiting doses that are not producing toxic or chronic drug-induced effects is a demand in drug development. Researchers found that $52 \%$ of patients receiving topical diclofenac sodium gel reported adverse events, such as: headache, abdominal pain, dyspepsia, nausea, pruritus, angina, palpitations, arrhythmia, venous thrombosis and elevation in creatinine and gastrointestinal bleeding $[4,35]$. In case of hepatotoxicity, viability and drug metabolizing capacities of the hepatocytes have been assessed. Acute diclofenac toxicity $(24 \mathrm{~h})$ was determined to be in the range of $\left(1 \times 10^{-5}-1 \times 10^{-3} \mathrm{~mol} / \mathrm{L}\right)$ concentrations [33]. 
The chronic toxicity investigated for 9 repeated doses of higher concentration $\left(6.4 \times 10^{-6}\right.$ and $100 \times 10^{-6}$ $\mathrm{mol} / \mathrm{L})$ was also tested. The toxic effects were observed starting from a very small clinically relevant concentration $\left(6.4 \times 10^{-6} \mathrm{~mol} / \mathrm{L}\right)$, that generates negative influences on exometabolome, induces apoptosis in hepatocytes [17] and might induce pseudoporphyria [50].

The toxicity assay is also requested for veterinary treatments and for environmental pollution of water. Based on the fact that the serum concentrations in adult horses of up to $10 \mathrm{ng} / \mathrm{mL}$ can be attained without adverse systemic effects [7] and due to the observation that the acute toxicity value for LC50 $48 \mathrm{~h}$ for Daphnia magna in water is $18.81 \pm 7.1$ $\mathrm{mg} / \mathrm{L}$ [41] there is a high demand to monitor toxic concentration levels to avoid harmful effects.

The analytical methods described in literature for the determination of diclofenac in tablets and human serum, rely mostly on spectrophotometry and HPLC [12]. These methods lack in providing a valid and fast methodology for its determination in routine analysis in pharmaceutical and clinic laboratories [48].

Early spectrophotometric methods for the determination of diclofenac in tablets containing also paracetamol, in the concentration range $10 \times 10^{-6}-80 \times 10^{-6} \mathrm{~g} / \mathrm{mL}$, are based on its capacity to reduce iron(III) to iron(II) when heated in aqueous solution. The ferrous ions form a coloured complex with 2,2-bipyridine having the maximum absorbance at $520 \mathrm{~nm}$ [2]. The drawbacks of UV-Vis spectrophotometric methods for the determination of diclofenac are the lack of sensitivity or simplicity. A more sensitive method used the basic dye methylene violet for its extractive spectrophotometric determination [46].

The need to selectively detect diclofenac in various media such as: human plasma and tap water, lead to the development of a supramolecular chemosensor based on 1,2,3-triazole [3]. The detection limit for diclofenac is $10 \times 10^{-6} \mathrm{~mol} / \mathrm{L}$ which recommends this sensor for monitoring its levels in different physiological, biological and environmental systems. A recent approach for monitoring diclofenac in spiked saliva samples [37] was based on the oxidation of diclofenac with potassium ferricyanide. Absorbance of the derivative in acetonitrile medium presented a linear calibration graph over the range of $2.5 \times 10^{-6}$ $60 \times 10^{-6} \mathrm{~mol} / \mathrm{L}$ with high precision.

In order to avoid optical interferences [20] silica nanomaterials functionalized with secondary antibodies and displaying $\mathrm{COOH}$ groups on the surface were used for the detection of diclofenac in water. A detection limit for DCF of $0.05 \times 10^{-6} \mathrm{~g} / \mathrm{mL}$ was reached, allowing to further use this method for analysing micropollutant pharmaceuticals in drinking and surface water samples.
Capillary zone electrophoresis was employed for the determination of diclofenac in human urine using a carbon fibre microelectrode. The limit of detection is $2.5 \times 10^{-6} \mathrm{~mol} / \mathrm{L}$ [25]. In recent years, the electrochemical and chromatographic methods [42] proved to be highly sensitive for the analysis of various drugs both in pharmaceutical products and also in human body fluids.

The square wave voltammetry method applied for the routine determination of diclofenac from urine samples, using plane pyrolytic graphite electrode, reached the lowest detection limit of $6.2 \times 10^{-9}$ $\mathrm{mol} / \mathrm{L}[18]$.

Other nanocomposites, consisting of $\mathrm{Cu}(\mathrm{OH})_{2}$ nanoparticles, the hydrophobic ionic liquid 1-ethyl-3methylimidazolium hexafluorophosphate and multiwalled carbon nanotubes were used for glassy carbon electrode modification exhibiting good electrocatalytic activity for the oxidation of diclofenac in blood serum and sea water [5]. The sensor proved its validity in the range of $0.18 \times 10^{-6}$ to $119 \times 10^{-6} \mathrm{~mol} / \mathrm{L}$.

Linear sweep voltammetry (LSV) and gas chromatography (GC) coupled with mass spectrometry (MS) proved to be highly efficient for diclofenac detection in the concentration range of $5 \times 10^{-6}-35 \times$ $10^{-6} \mathrm{~g} / \mathrm{mL}$ for LSV and $0.25 \times 10^{-6}-5 \times 10^{-6} \mathrm{~g} / \mathrm{mL}$ for GC-MS method. Despite its fastness and precision, expensive equipment is needed $[43,55]$. The use of diclofenac in the presence of morphine for the treatment of various diseases was monitored in urine samples using a 1-methyl-3-butylimidazolium chloride modified NiO/CNTs carbon paste electrode [10]. A simple and sensitive method for the determination of diclofenac was based on redox properties of Cobalt hexacyanoferrate deposited on multi-walled carbon nanotubes (MWCNTs). The diclofenac concentration range was $1.0 \times 10^{-3}-100.0 \times 10^{-3} \mathrm{~mol} / \mathrm{L}$ with detection limit of $0.3 \times 10^{-3} \mathrm{~mol} / \mathrm{L}[10]$.

Novel approaches are based on using nanomaterials, such as nanogold, that brought benefits for diclofenac detection due to its large surface area, enhancement of electron transfer, good biocompatibility and high conductivity [1]. A sensor for the determination of diclofenac based on gold nanoparticle/multi-walled carbon nanotube modified glassy carbon electrode was reported to give an excellent response in the range of $0.03 \times 10^{-6}-200 \times 10^{-6} \mathrm{~mol} / \mathrm{L}$.

Many attempts to detect and monitor diclofenac levels in pharmaceutical preparations [44] in the presence of several substances by means of potentiometric methods were reported during time. The system $\mathrm{Pt}|\mathrm{Hg}| \mathrm{Hg}_{2}(\mathrm{DCF})_{2} \mid$ graphite responds to diclofenac with Nernstian sensitivity over a wide linear range $5.0 \times 10^{-5}$ to $1.0 \times 10^{-2} \mathrm{~mol} / \mathrm{L}$ at $\mathrm{pH} 6.5-$ 9.0 [44].

A PVC membrane sensor based on its ion pair complex with silver for diclofenac detection demonstrated also 
FARMACIA, 2018, Vol. 66, 3

a Nernstian response in the range of $5.2 \times 10^{-5}$ to $1.1 \times 10^{-2} \mathrm{~mol} / \mathrm{L}$ [31].

The heterocyclic compounds already demonstrated their ability to coordinate anions, so that their use to remove or detect diclofenac was tested. In order to remove diclofenac from contaminated waters calix[4]arenes products were used as versatile receptors [11]. The porphyrins are easily implied in host guest processes and due to this property are used for potentiometric sensors formulations. The potentiometric response for $\mathrm{Fe}$ (III) tetraphenylporphyrin-chloride and $\mathrm{Fe}(\mathrm{III})$ tetrakis(pentafluorophenyl) porphyrin chloride based membranes to diclofenac was studied in different mediator solvents and using several ionic additives [45]. The best result was obtained by $\mathrm{Fe}(\mathrm{III}) \mathrm{TPFPP}-\mathrm{Cl}$ ionophore in $o$-nitrophenyloctylether, showing a linear response towards diclofenac concentrations between $10^{-5}$ and $10^{-2} \mathrm{~mol} / \mathrm{L}$.

A better performance was obtained by using as ionophores two different metalloporphyrins $\mathrm{Mn}$ (III) tetraphenylporphyrin chloride and manganese(III)tetrakis(3-hydroxyphenyl)porphyrin chloride [52] for the construction of new diclofenac-selective electrodes. The best result (linear response in the concentration range $3 \times 10^{-6}-1 \times 10^{-2} \mathrm{~mol} / \mathrm{L}$ ) was obtained for the PVC membrane based on Mn(III) tetraphenylporphyrin chloride plasticized with dioctylphtalate and having sodium tetraphenylborate as a lipophilic anionic additive.

The substitution of the toxic mercury electrodes by the more environmentally friendly porphyrin modified electrodes is an actual trend of sustainable chemistry [39]. An amperometric method for the analysis of sodium/potassium diclofenac on a glassy carbon electrode modified with films of a tetraruthenated(II) cobalt(III)-porphyrin achieved low limits of detection $\left(8.1 \times 10^{-8} \mathrm{~mol} / \mathrm{L}\right)$.

Diclofenac was also analysed with a detection limit of $1.9 \times 10^{-5} \mathrm{~mol} / \mathrm{L}$ using modified Ag colloids with thiocholine bromide, thus creating particles where the zeta potential is switched from negative to positive values [49].

Taking into consideration the unfavourable pharmacokinetic properties of drugs and the need to assess the associated risks [8], this work continues previous investigation using gold [1] and nanogold-porphyrin hybrids $[14,47]$ on one hand, and porphyrins $[9$, $15,30]$ on the other hand, for biologically relevant compounds detection.

The effects generated between the noble metals nanoparticles and the porphyrins are comparatively presented in a complex study regarding diclofenac sodium detection with the purpose to help monitoring long term treated patients that might develop chronic toxicity $\left(10^{-5}-10^{-4} \mathrm{~mol} / \mathrm{L}\right)$ [51]. A water soluble zinc-metalloporphyrin, Zn(II)-tetra-(4-N-methyl-4pyridyl)porphyrin chloride (Figure 1), was used alone and compared with its hybrid with gold nanoparticles and with solely gold nanoparticles for the efficient optical detection of diclofenac.

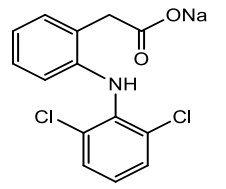

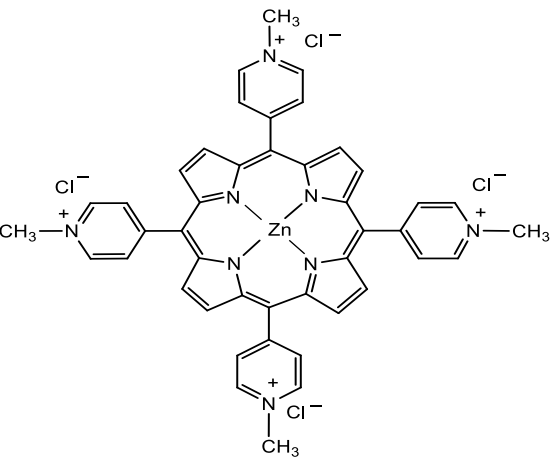

b

Figure 1.

The structure of: diclofenac: 2-[(2,6-ichlorophenyl)amino]benzeneacetic acid sodium salt (a) and of 5,10,15,20tetrakis( $N$-methyl-4-pyridyl)porphyrin-Zn(II) tetrachloride (b)

\section{Materials and Methods}

\section{Reagents}

The used solvents and reagents in the highest purity available (THF, DMF, acetonitrile, methanol, chloroform, zinc chloride, methyl tosilate) were purchased from Merck. Silica gel plates 60 (230 400 mesh, $0.040-0.063 \mathrm{~mm}), \mathrm{F}_{254}$ were purchased from Merck. Dowex resin 1X2 $\mathrm{Cl}^{-} 200-400 \mathrm{~nm}$ was acquired from Dow Chemicals, Midland, (MI).
Synthesis of Zn(II)-tetra-(4-N-methyl-4-pyridyl)porphyrin tetrachloride (ZnTMePyP)

A mixture comprised of meso-tetra (4-pyridyl)porphyrin $(0.618 \mathrm{~g}, 1 \mathrm{mmol})$ and methyl-4-methylbenzene-sulfonate $(0.93 \mathrm{~g}, 5 \mathrm{mmol})$ in $150 \mathrm{~mL} \mathrm{DMF}$ was refluxed for 4 - 10 hours under argon atmosphere. The methylation process was monitored by TLC using silica gel plates and as eluent a mixture of acetonitrile/water $\left(\mathrm{sat} . \mathrm{KNO}_{3}\right)=8 / 1(\mathrm{v} / \mathrm{v})[13,19,36]$. When methylation was complete, the mixture was 
FARMACIA, 2018, Vol. 66, 3

dried under vacuum, dissolved in distilled water and the impurities were extracted with chloroform. The water fraction is filtered and vacuum evaporated, giving the tetra(4-methyl-pyridyl)porphyrin tetratosilate. The tetra(4-methyl-pyridyl)porphyrin tosilate salt was then dissolved in $80 \mathrm{~mL} \mathrm{HCl}$ acidulated $\mathrm{H}_{2} \mathrm{O}$ (the resulting solution having the concentration of $0.1 \mathrm{~N} \mathrm{HCl}$ ) and $15 \mathrm{~mL}$ methanol. This solution is slowly drained through an ion exchange column filled with Dowex 1X2 $\mathrm{Cl}^{-} 200-400 \mathrm{~nm}$ resin for the substitution of tosilate anion with chloride ion, generating a more water soluble compound. The high purity porphyrin is obtained by a new vacuum evaporation. The metalation with $\mathrm{Zn}$ was realized applying the classical method $[6,24]$ with a large excess of $\mathrm{Zn}$ chloride.

The gold colloid ( $n$-Au) synthesis:

The gold colloid with spherical dimensions in a narrow range $(15-20 \mathrm{~nm})$ was synthesized in an environmentally friendly manner [34] following the previous reported recipe [14].

Obtaining of the ZnTMePyP/n-Au hybrid:

The formation of the hybrid material composed from $\mathrm{Zn}$ (II)-tetra-(4-N-methylpyridyl)porphyrin tetrachloride and gold colloidal particles was accomplished by adding small portions of $\mathrm{HCl}$ acidulated $\mathrm{Zn}$ porphyrin solution $\left(\mathrm{c}=10^{-5} \mathrm{~mol} / \mathrm{L}, \mathrm{pH}=3\right)$ to $3 \mathrm{~mL}$ diluted gold colloid solution $\left(\mathrm{c}=4.58 \times 10^{-4} \mathrm{~mol} / \mathrm{L}\right)$, under stirring, at room temperature, as follows: $20 \mu \mathrm{L}$ Zn-porphyrin solution up to sample 7; $100 \mu \mathrm{L}$ up to sample 22; $150 \mu \mathrm{L}$ up to sample 32 . The generation of complex was monitored by UV-Vis spectroscopy (Figure 2).

Spectrophotometric detection of diclofenac by the ZnTMePyP/n-Au hybrid, bare Zn-porphyrin and nAu alone, respectively

Diclofenac solution (20 $\mu \mathrm{L}$ portions) having the concentration of $9.9 \times 10^{-3} \mathrm{~mol} / \mathrm{L}$, in doubly distilled water, was successively added to $3 \mathrm{~mL}$ of each investigated solution: ZnTMePyP/n-Au hybrid, bare ZnTMePyP and bare gold colloid, under stirring. After 30 seconds the UV-Vis spectrum was recorded for each sample.

$U V$-Vis spectrometry

Spectrophotometric measurements were performed in $1 \mathrm{~cm}$ wide quartz cuvettes on a JASCO model V-650 spectrometer.

\section{STEM Microscopy}

STEM images were obtained using a Titan G2 80 200 TEM/STEM microscope (FEI Company, The Netherlands). Samples were prepared by drop-casting the gold-porphyrin hybrids with and without diclofenac from water mixtures on 200 mesh TEM copper grids coated with continuous carbon film. The images were registered at $200 \mathrm{kV}$ using TEM Imaging \& Analysis v. 4.7 software.

\section{Results and Discussion}

$U V$-Vis monitoring of the synthesis of ZnTMePyP/n$A u$ hybrid showed that the successive adding of acidulated solution of Zn-porphyrin to the gold colloid solution has the general effect of widening the absorption spectrum of the hybrid material (Figure 2). Thus, it can be observed that the gold colloid alone has the maximum absorption at $522 \mathrm{~nm}$, whereas the hybrid material expands its absorption domain from $400 \mathrm{~nm}$ to $900 \mathrm{~nm}$. Two isosbestic points located at $410 \mathrm{~nm}$ and $455 \mathrm{~nm}$ on either side of the Soret band of the Zn-porphyrin (436 nm), are indicative for the two intermediate specia formed during the hybrid generation. The two equilibrium processes might be associated on one hand with the interaction between the negatively charged surface of the gold colloidal particles and the four $\mathrm{N}^{+}-\mathrm{CH}_{3}$ functional groups of the porphyrin and on the other hand with the formation of supramolecular structures [53]. Such supramolecular architectures are due to the strong $\pi-\pi$ intermolecular interactions of $\mathrm{Zn}$ porphyrin complex, that are promoting $\mathrm{n}-\mathrm{Au}$ particles to form side-by-side assemblies (Figure 4). The large flat band that is finally formed from $600 \mathrm{~nm}$ to $900 \mathrm{~nm}$ is in relation to the HOMO-LUMO levels of the zinc-porphyrin coupled to the $\mathrm{n}$-Au surface plasmon [27].

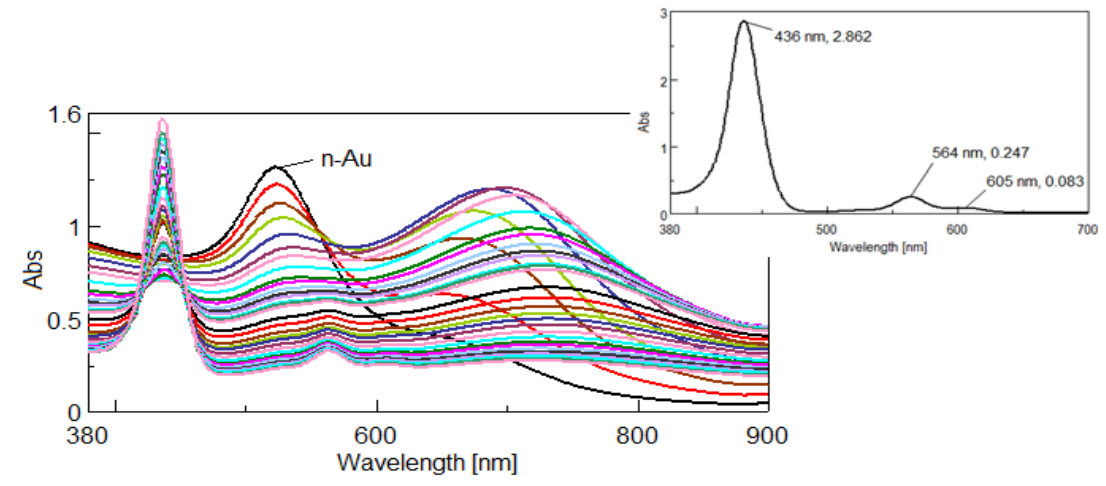

Figure 2.

UV-Vis monitoring of the synthesis of ZnTMePyP/n-Au hybrid. Detail of the UV-Vis spectrum of the initial porphyrin 
The STEM and TEM microscopy (Figure 3, a, b, c) of the acidified ZnTMePyP showed its preference to triangular platelet aggregation and the second image offers a frame with TEM measurements of interplanar distances of $2.80 \mathrm{~nm}$ from solid crystalline state. A larger STEM image shows clearly dendritic assembling of the $\mathrm{Zn}$-porphyrin triangular aggregates.
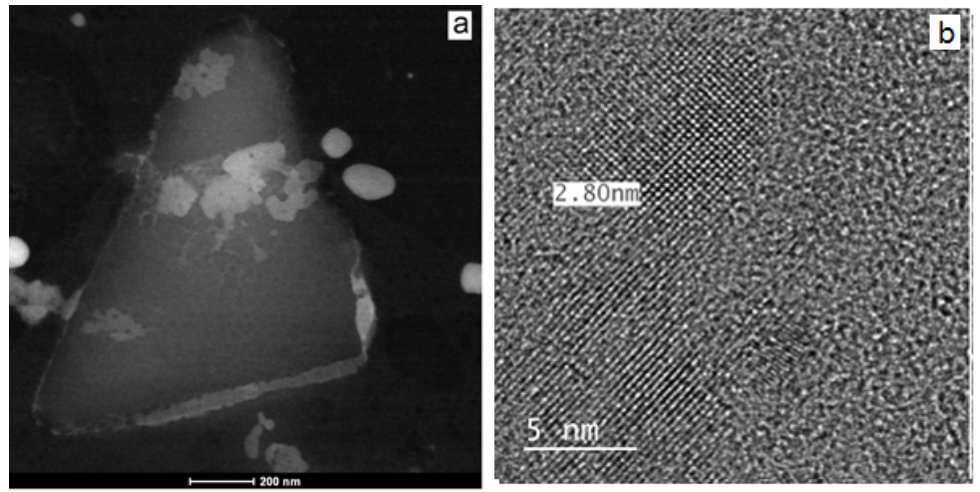

Figure 3.
The STEM investigations (Figure 4) focused on the interaction between ZnTMePyP and gold nanoparticles, showed that the colloidal gold assembled by side-by-side process on the surface of large spherical or egg-like porphyrin aggregates generated by the self-assembly of water-soluble Zn-porphyrin.
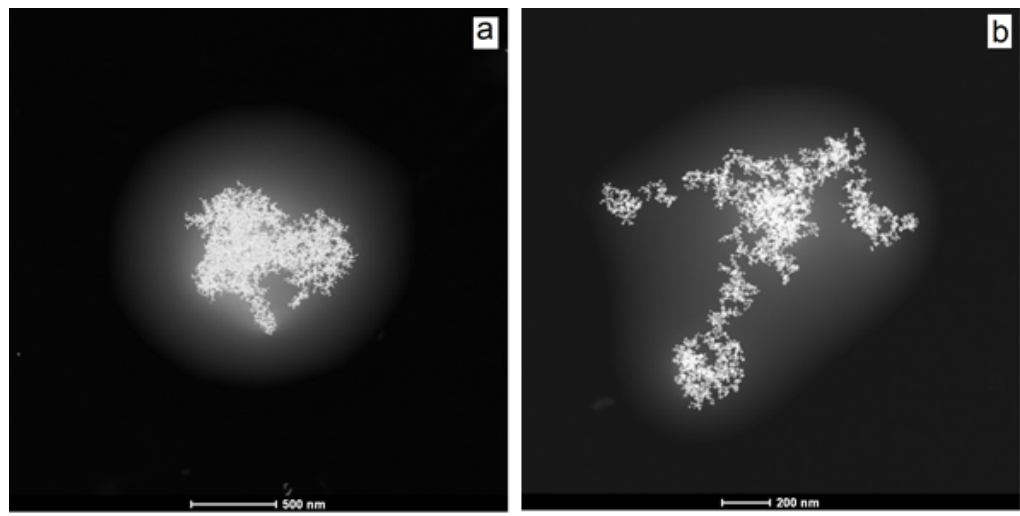

Figure 4.

STEM images of the ZnTMePyP/n-Au hybrid

The diclofenac detection using ZnTMePyP/n-Au hybrid

Diclofenac solution (20 $\mu \mathrm{L}$ portions) having the concentration of $9.9 \times 10^{-3} \mathrm{~mol} / \mathrm{L}$, in doubly distilled water, was successively added to $3 \mathrm{~mL}$ of $\mathrm{ZnTMePyP} / \mathrm{n}-\mathrm{Au}$ hybrid, under stirring and the $\mathrm{UV}-\mathrm{V}$ is spectra were registered.

By increasing the diclofenac concentration (Figure 5a), the intensity of absorption of the hybrid decreased in intensity, so that in the range of $1.94 \times 10^{-5} \mathrm{~mol} / \mathrm{L}$ to $7.34 \times 10^{-5} \mathrm{~mol} / \mathrm{L}$ the intensity of absorption was linearly dependent with the diclofenac concentration (Figure 5b).

The correlation coefficient of the linear dependence was excellent and had a value of $99.61 \%$. After a certain concentration of diclofenac was reached, the shape of the spectra and the intensity of the Soret band increased again, a fact that insures that the process of detection is not mimed by the diluting of the solution.

The accuracy of diclofenac detection and the range of the concentrations recommend the use of this simple method for the water toxicity analysis and for low levels of chronic toxicity in patients with long treatment prescription. The AFM (Figure 6, shadow technique maps) images of the $\mathrm{ZnTMePyP} / \mathrm{n}-\mathrm{Au}$ hybrid, after treating it with diclofenac show that the material, due to diclofenac interaction, is reorganized in a uniformly manner. Triangular aggregates that are characteristic for Zn-metalloporphyrin, and that are similar in size and preserving the same orientation are built in successive layers like a tile roof, by concomitant $\mathrm{H}$ - and J-type aggregations. The thick of the deposited layers differs, but there is no lack of continuity. Some clearly displayed small spheres, might be the $n-A u$ associated particles. 


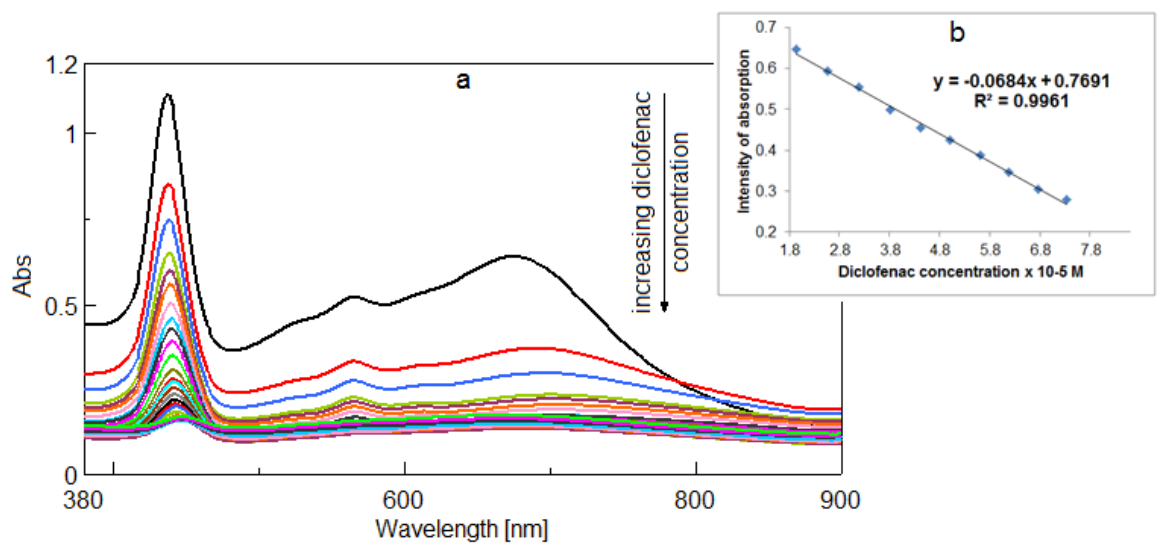

Figure 5.

The superposed UV-Vis spectra of the ZnTMePyP/n-Au hybrid treated with increased diclofenac concentrations (a) and the dependence between the intensity of absorption and the diclofenac concentration (b)

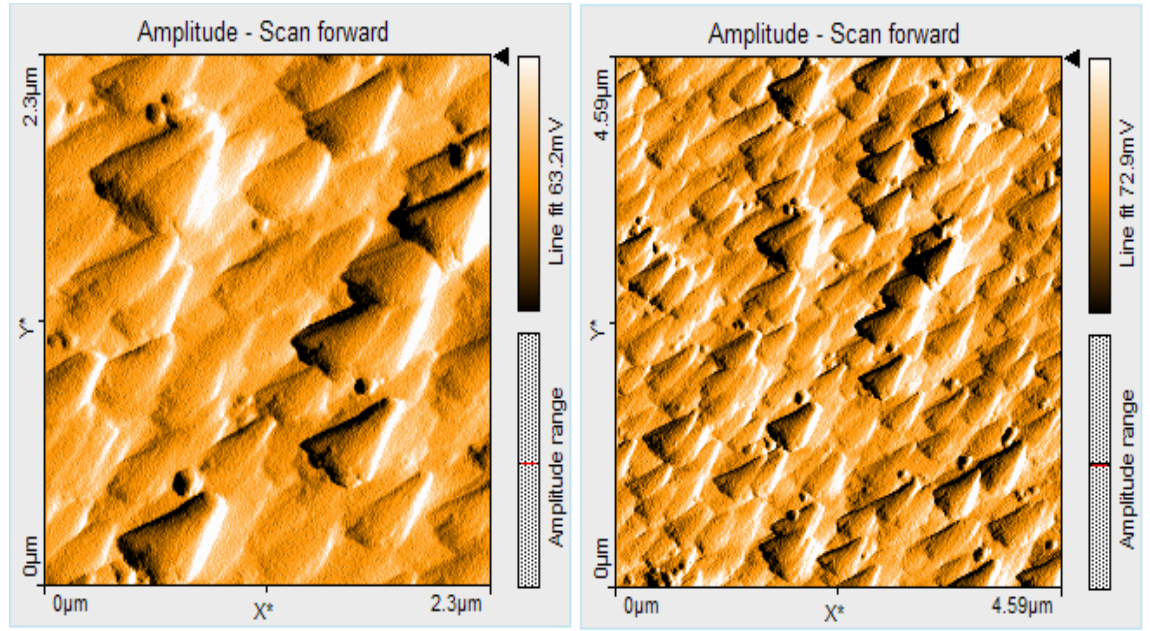

Figure 6.

The AFM (shadow technique maps) images of the ZnTMePyP/n-Au hybrid, after treating it with diclofenac

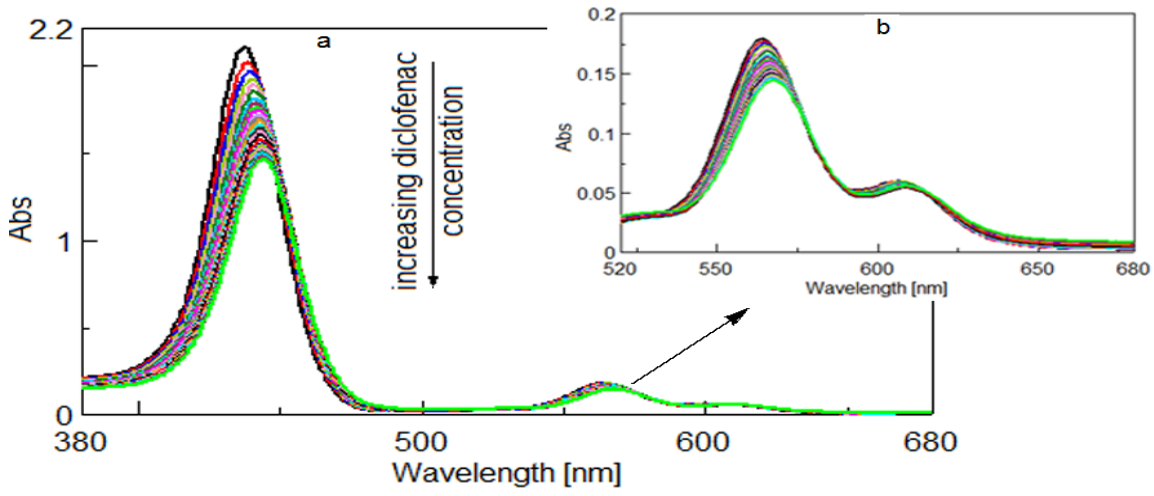

Figure 7.

The superposed UV-Vis spectra of the ZnTMePyP treated with increased diclofenac concentrations (a) and detail of the $\mathrm{Q}$ bands (b)

The diclofenac detection using solely ZnTMePyP Respecting the same methodology that was described for the detection of diclofenac using the ZnTMePyP/n$\mathrm{Au}$ hybrid, the UV-Vis spectra were presented in Figure 7 for the detection using solely ZnTMePyP. Four isosbestic points, located at $450 \mathrm{~nm}$ on the
Soret band and $534 \mathrm{~nm}, 577 \mathrm{~nm}$ and $590 \mathrm{~nm}$ on the Q bands of the metalloporphyrin were evidenced, proving that a complex is formed between the $\mathrm{Zn}$ porphyrin and the diclofenac during the detection procedure. Many equilibrium processes are involved that might be explained by the complexity of interactions 
between the $\mathrm{Zn}$-porphyrin and the diclofenac molecule. Zinc atom might offer coordination space for the pharmaceutical compound, but in concurrence with the porphyrin macrocycle that can interact with the carboxylate anion of the diclofenac.

The concentration domain for which the intensity of absorption of the ZnTMePyP is linearly dependent with the diclofenac concentration is $2.57 \times 10^{-5} \mathrm{~mol} / \mathrm{L}$ to $1.41 \times 10^{-4} \mathrm{~mol} / \mathrm{L}$ (Figure 8 ), proving surprisingly a larger domain of detecting capacity than that of the hybrid formed with the gold colloid. The confidence coefficient of the linear dependence was also very good, of $99.23 \%$.

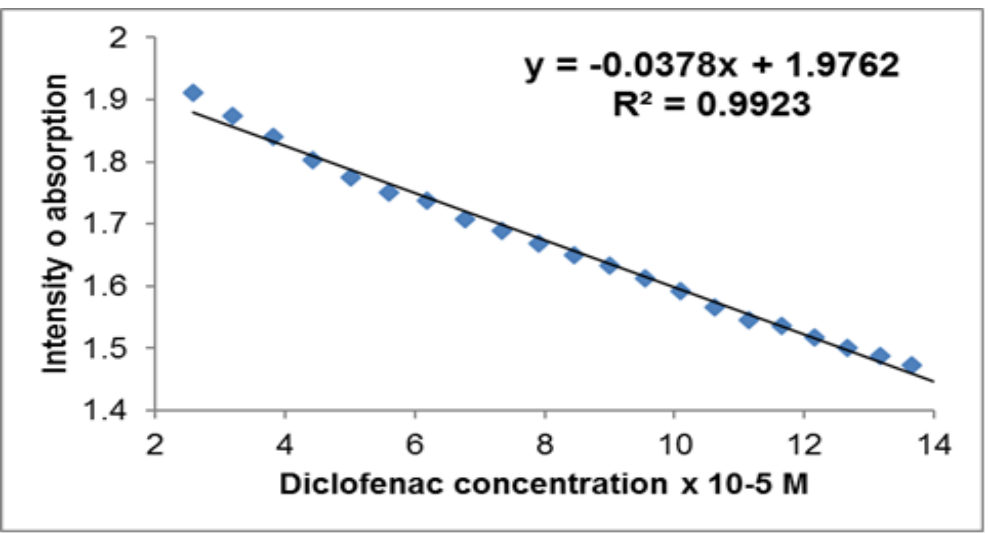

Figure 8.

The dependence between the intensity of absorption and the diclofenac concentration

The diclofenac detection using solely $n-A u$

The experiment was continued, in order to inspect what results if the simple gold is treated with diclofenac. After analysing the shape of the superposed UV-Vis spectra (Figure 9), it can be concluded that the effect of diclofenac upon the absorption intensity of the gold plasmon is only that of the mixture dilution.

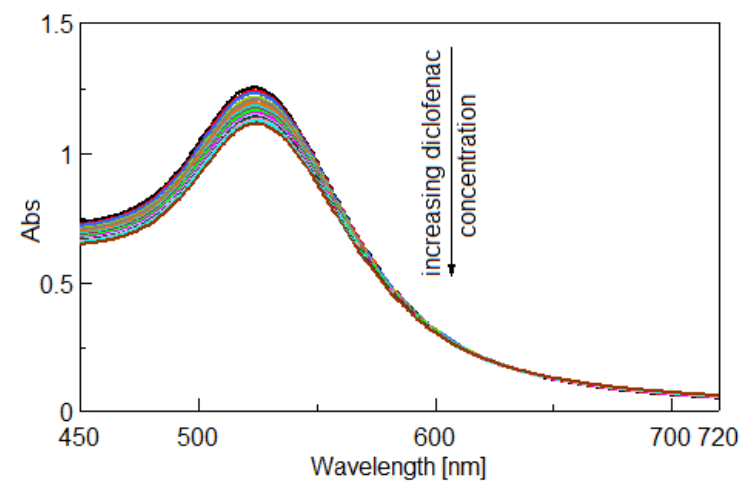

Figure 9.

The dependence between the intensity of absorption and the diclofenac concentration

\section{Conclusions}

Our attempts to provide some spectroscopically novel nanostructured materials that can detect chronic toxicity levels of diclofenac gave promising results. The investigation was focused on the detection capabilities of a water soluble metalloporphyrin ZnTMePyP, of tailored spherical size gold nanoparticles $(15-20 \mathrm{~nm}) \mathrm{n}$-Au and on the hybrid nanomaterial $\mathrm{ZnTMePyP} / \mathrm{n}-\mathrm{Au}$ formed between them.
The generation of the hybrid was discussed and investigated by UV-Vis and microscopic techniques. Regarding the diclofenac detection, it can be stated that the water soluble Zn-porphyrin alone can detect diclofenac in a larger domain of concentration than the hybrid formed between the metalloporphyrin and that the gold nanoparticles alone are not capable of diclofenac detection. The concentration domain of diclofenac detection in a reliable fashion is $2.57 \mathrm{x}$ $10^{-5}-14.15 \times 10^{-5} \mathrm{~mol} / \mathrm{L}$. The method chosen for detection, UV-Vis spectroscopy, implies neither expensive equipment, nor the lengthy preparation of the samples, thereby providing a simple and time-efficient method to assess the chronic toxicity of diclofenac in the biological fluids of patients that were long time treated with this medicine.

\section{Acknowledgement}

The authors kindly recognize the support from UEFISCDI, the project PN III No. 107 PED/03.01.2017 CorOxiPor and from Romanian Academy, Program 3 - Porphyrins/2017.

\section{References}

1. Afkhami A, Bahiraei A, Madrakian T, Gold nanoparticle/multi-walled carbon nanotube modified glassy carbon electrode as a sensitive voltammetric sensor for the determination of diclofenac sodium. Mater Sci Eng C, 2016; 59: 168-176.

2. Agrawal YK, Shivramchandra K, Visible spectrophotometric method for determination of diclofenac sodium. J Pharm Biomed Anal., 1991; 9: 97-100.

3. Ahmed F, Shah K, Awan IZ, Shah MR, Triazolebased highly selective supramolecular sensor for 
FARMACIA, 2018, Vol. 66, 3

the detection of diclofenac in real samples. Ecotoxicol Environ Saf., 2016; 129: 103-108.

4. Altman RD, Dreiser RL, Fisher CL, Chase WF, Dreher DS, Zacher J, Diclofenac sodium gel in patients with primary hand osteoarthritis: A randomized, double-blind, placebo-controlled trial. J Rheumatol., 2009; 36: 1991-1999.

5. Arvand M, Gholizadeh TM, Zanjanchi MA, MWCNTs $/ \mathrm{Cu}(\mathrm{OH})_{2}$ nanoparticles/IL nanocomposite modified glassy carbon electrode as a voltammetric sensor for determination of the non-steroidal antiinflammatory drug diclofenac. Mater Sc. Eng C, 2012; 32: 1682-1689.

6. Bailey SL, Hambright P, Kinetics of the reactions of divalent copper, zinc, cobalt and nickel with a deformed water soluble centrally monoprotic porphyrin. Inorg Chim Acta, 2003; 344: 43-48.

7. Barnett SE, Sellon DC, Hines MT, Seino KK, Knych HK, Randomized, controlled clinical trial of safety and plasma concentrations of diclofenac in healthy neonatal foals after repeated topical application of $1 \%$ diclofenac sodium cream. Am J Vet Res., 2017; 78: 405-411.

8. Chuasuwan B, Binjesoh V, Polli JE, Zhang H, Amidon GL, Junginger HE, Midha K K, Shah VP, Stavchansky S, Dressman JB, Barends DM, Biowaiver monographs for immediate release solid oral dosage forms: diclofenac sodium and diclofenac potassium. J Pharm Sci., 2009; 98(4): 1206-1219.

9. Creanga I, Palade A, Lascu A, Birdeanu M, Fagadar-Cosma G, Fagadar-Cosma E, Manganese(III) porphyrin sensitive to $\mathrm{H}_{2} \mathrm{O}_{2}$ detection. Dig $J$ Nanomat Bios., 2015; 10(1): 315-321.

10. Damiri S, Mosaei Oskoei Y, Fouladgar M, Highly sensitive voltammetric and impedimetric sensor based on an ionic liquid/cobalt hexacyanoferrate nanoparticle modified multi-walled carbon nanotubes electrode for diclofenac analysis. $J$ Experim Nanosci., 2016; 11: 1384-1401.

11. Danil de Namor A F, Al Nuaima M, Villanueva Salas JA, Bryant S, Howlin B, A calix[4]arene derivative and its selective interaction with drugs (clofibric acid, diclofenac and aspirin). Eur $J$ Pharm Sci., 2017; 100: 1-8.

12. Elkady E, Simultaneous determination of diclofenac potassium and methocarbamabol in ternary mixture with guaifenesin by reverse phase liquid chromatography. Talanta, 2016; 82: 1604-1607.

13. Engelmann FM, Losco P, Winnischofer H, Araki $\mathrm{K}$, Toma HE, Synthesis, electrochemistry, spectroscopy and photophysical properties of a series of mesophenylpyridylporphyrins with one to four pyridyl rings coordinated to $\left[\mathrm{Ru}(\text { bipy })_{2} \mathrm{Cl}\right]^{+}$groups. J Porphyr Phthalocyanines, 2002; 6: 33-42.

14. Fagadar-Cosma E, Sebarchievici I, Lascu A, Creanga I, Palade A, Birdeanu M, Taranu B, Fagadar-Cosma G, Optical and electrochemical behavior of new nanosized complexes based on gold-colloid and Coporphyrin derivative in the presence of $\mathrm{H}_{2} \mathrm{O}_{2} . J$ Alloys Compd., 2016; 686: 896-904.

15. Fagadar-Cosma E, Vlascici D, Fagadar-Cosma G, Palade A, Lascu A, Creanga I, Birdeanu M, Cristescu $\mathrm{R}$, Cernica I, A Sensitive $\mathrm{A}_{3} \mathrm{~B}$ porphyrin nanomaterial for $\mathrm{CO}_{2}$ detection. Molecules, 2014; 19: 21239-21252.
16. Francio VT, Davani S, Towery C, Brown TL, Oral versus topical diclofenac sodium in the treatment of osteoarthritis. J Pain Palliat Care Pharmacother., 2017; 7: 1-8.

17. Gómez-Lechón MJ, Ponsoda X, O'Connor E, Donato T, Jover R, Castell JV, Diclofenac induces apoptosis in hepatocytes. Toxicol In Vitro, 2003; 17: 675-680.

18. Goyal RN, Chatterjee S, Agrawal B, Electrochemical investigations of diclofenac at edge plane pyrolytic graphite electrode and its determination in human urine. Sens Actuat B-Chem., 2010; 145: 743-748.

19. Hambright $P$, Gore $T$, Burton M, Synthesis and characterization of new isomeric water-soluble porphyrins. Tetra(2-N-methylpyridyl)porphine and tetra(3-N-methylpyridyl)porphine. Inorg Chem., 1976; 15(9): 2314-2315.

20. Hlaváček A, Farka Z, Hübner M, Horňáková V, Němeček D, Niessner R, Skládal P, Knopp D, Gorris HH, Competitive upconversion-linked immunosorbent assay for the sensitive detection of diclofenac. Anal Chem., 2016; 88: 6011-6017.

21. Hui X, Hewitt PG, Poblete N, Maibach HI, Wester $\mathrm{RC}$, In vivo bioavailability and metabolism of topical diclofenac lotion in human volunteer. Pharm Res., 1998; 15 (10): 1589-1595.

22. Iancu V, Roncea $F$, Cazacincu RG, Lupu CE, Miresan H, Danaila CN, Rosca C, Lupuleasa D, Response surface methodology for optimization of diclofenac sodium orodispersible tablets. Farmacia, 2016; 64(2): 210-216.

23. Iliescu T, Baia M, Miclaus V, A Raman spectroscopic study of the diclofenac sodium-betacyclodextrin interaction. Eur J Pharm Sci., 2004; 22: 487-495.

24. Ishikawa Y, Yamakawa N, Uno T, Synthetic control of interchromophoric interaction in cationic bis-porphyrins toward efficient DNA photocleavage and singlet oxygen production in aqueous solution. Bioorg Med Chem., 2007; 15: 5230-5238.

25. Jin W, Zhang J, Determination of diclofenac sodium by capillary zone electrophoresis with electrochemical detection. J Chromatogr., 2000; 868: 101-107.

26. John R, Herzenberg AM, Renal toxicity of therapeutic drugs. J Clin Pathol., 2009; 62: 505-515.

27. Kocherzhenko AA, Patwardhan S, Grozema FC, Anderson HL, Siebbeles LDA, Mechanism of charge transport along zinc porphyrin-based molecular wires. J Am Chem Soc., 2009; 131(15): 5522-5529.

28. Kusai I, Vlase L, Tomuţă I, Leucuţa SE, Kinetic modeling of hydration hydrophilic matrices with diclofenac sodium on basis of hydroxypropyl methyl-cellulose and xanthan gum. Farmacia, 2008; 4: 371-380.

29. Lai PM, Collaku A, Reed K, Efficacy and safety of topical diclofenac/menthol gel for ankle sprain: A randomized, double-blind, placebo- and activecontrolled trial. J Int Med Res., 2017; 45(2): 647-661.

30. Li Q, Huie CW, Coupling of acetonitrile deproteinization and salting -out extraction with acetonitrile stacking for biological sample clean -up and the enrichment of hydrophobic compounds (porphyrins) in capillary electrophoresis. Electrophoresis, 2006; 27: 4219-4229. 
FARMACIA, 2018, Vol. 66, 3

31. Maleki R, Matin AA, Hosseinzadeh R, Jouyban A, PVC membrane sensor for diclofenac: applications in pharmaceutical analysis and drug binding studies, Pharmazie, 2007; 62: 672-677.

32. Metri M, Hegde S, Bhandi S, Effect of pretreatment diclofenac sodium on postendodontic pain: A randomised controlled trial. J Conserv Dent, 2016; 19: 7-10.

33. Mueller D, Müller-Vieira U, Biemel KM, Tascher G, Nüssler AK, Noor F, Biotransformation of diclofenac and effects on the metabolome of primary human hepatocytes upon repeated dose exposure. Eur J Pharm Sci., 2012; 45: 716-724.

34. Muthukumar P, Abraham John S, Gold nanoparticles decorated on cobalt porphyrin-modified glassy carbon electrode for the sensitive determination of nitrite ion. J Colloid Interf Sci., 2014; 421: 78-84.

35. Nair B, Taylor-Gjevre R, A review of topical diclofenac use in musculoskeletal disease. Pharmaceuticals (Basel), 2010; 3: 1892-1908.

36. Ohyama $\mathrm{T}$, Mita $\mathrm{H}$, Yamamoto $\mathrm{Y}$, Binding of 5,10,15,20-tetrakis(N-methylpyridinium-4-yl)-21H, $23 \mathrm{H}$-porphyrin to an AT-rich region of a duplex DNA. Biophys Chem., 2005; 113(1): 53-59.

37. Pochivalov A, Vakh C, Andruch V, Moskvin L, Bulatov A, Automated alkaline-induced salting-out homogeneous liquid-liquid extraction coupled with in-line organic-phase detection by an optical probe for the determination of diclofenac, Talanta, 2017; 169: 156-162.

38. Probst M, Kühn JP, Modeß C, Scheuch E, Seidlitz A, Hosten N, Siegmund W, Weitschies W, Muscle injury after intramuscular administration of diclofenac: a case report supported by magnetic resonance imaging. Drug Saf Case Rep., 2017; 4(1): 1-5.

39. Quintino MSM, Araki K, Toma HE, Angnes L, Amperometric quantification of sodium metabisulfite in pharmaceutical formulations utilizing tetraruthenated porphyrin film modified electrodes and batch injection analysis. Talanta, 2006; 68: 1281-1286.

40. Roskar R, Kmetec V, Liquid chromatographic determination of diclofenac in human synovial fluid. J Chromatogr B, 2003; 788: 57-64.

41. Rozas O, Vidal C, Baeza C, Jardim WF, Rossner A, Mansilla HD, Organic micropollutants (OMPs) in natural waters: Oxidation by $\mathrm{UV} / \mathrm{H}_{2} \mathrm{O}_{2}$ treatment and toxicity assessment. Water Res., 2016; 98: 109-118.

42. Rubim AM, Bandeira Rubenick J, Laporta LV, Bueno Rolim CM, A simple method for the quantification of diclofenac potassium in oral suspension by high-performance liquid chromatography with UV-detection. Braz J Pharm Sci., 2013; 49: 589-597.

43. Sanati AL, Karimi-Maleh H, Badiei A, Biparva P, Ensafi AA, A voltammetric sensor based on $\mathrm{NiO} / \mathrm{CNTs}$ ionic liquid carbon paste electrode for determination of morphine in the presence of diclofenac. Mater Sci Eng C, 2014; 35: 379-385.

44. Santini AO, Pezza HR, Pezza L, Determination of diclofenac in pharmaceutical preparations using a potentiometric sensor immobilized in a graphite matrix. Talanta, 2006; 68: 636-642.

45. Santos EMG, Araujo AN, Couto CMCM, Montenegro MCBSM, Potentiometric behaviour of ion selective electrodes based on iron porphyrins: The influence of porphyrin substituents on the response properties and analytical determination of diclofenac in pharmaceutical formulations. $J$ Pharm Biomed Anal., 2006; 42: 535-542.

46. Sastry CP, Prasad T, Suryamarayana MV, Spectrophotometric method for determination of diclofenac sodium in bulk samples and pharmaceutical preparations. Analyst, 1989; 114: 513-516.

47. Sebarchievici I, Tăranu BO, Birdeanu M, Rus SF, Făgădar-Cosma E, Electrocatalytic behavior and application of manganese porphyrin/gold nanoparticle- surface modified glassy carbon electrodes. Appl Surf Sci., 2016; 390: 131-140.

48. Souza R, Tubino M, Spectrophotometric determination of diclofenac on pharmaceutical preparation. J Braz Chem Soc., 2005; 16: 1068-1073.

49. Stewart A, Murray S, Bell SE, Simple preparation of positively charged silver nanoparticles for detection of anions by surface-enhanced Raman spectroscopy. Analyst, 2015; 140: 2988-2994.

50. Turnbull N, Callan M, Staughton RC, Diclofenacinduced pseudoporphyria; an under-recognized condition? Clin Exp Dermatol., 2014; 39: 348-350.

51. Van Den Abeele J, Brouwers J, Mattheus R, Tack J, Augustijns P, Gastrointestinal behavior of weakly acidic BCS class II drugs in MandCase study of diclofenac potassium. J Pharm Sci., 2016; 105: 687-696.

52. Vlascici D, Pruneanu S, Olenic L, Pogacean F, Ostafe V, Chiriac V, Pica EM, Bolundut LC, Nica L, Fagadar-Cosma E, Manganese(III) porphyrinbased potentiometric sensors for diclofenac assay in pharmaceutical preparations. Sensors, 2010; 10: 8850-8864.

53. Xue C, Birel O, Li Y, Ma X, Gao M, Urbas A, Li $\mathrm{Q}$, Porphyrin metal complex monolayer-protected gold nanorods: A parallel facile synthesis and selfassembly. J Colloid Interface Sci., 2013; 398: 1-6.

54. Yarishkin OV, Hwang EM, Kim D, Yoo JC, Kang SS, Kim DR, Shin JHJ, Chung HJ, Jeong HS, Kang D, Han J, Park JY, Hong SG, Diclofenac, a nonsteroidal anti-inflammatory drug, inhibits L-type $\mathrm{Ca}$ channels in neonatal rat ventricular cardiomyocytes. Korean J Physiol Pharmacol., 2009; 13(6): 437442.

55. Yilmaz B, Ciltas U, Determination of diclofenac in pharmaceutical preparations by voltammetry and gas chromatography methods. J Pharmaceutical Analysis, 2015; 5(3): 153-160. 